\title{
Cytokines in Proliferative Vitreoretinopathy
}

\author{
G. A. LiMB,${ }^{*}$ B. C. LITTLE, ${ }^{* *}$ A. MEAGER,$\dagger$ J. A. OGILVIE,${ }^{*}$ R. A. \\ WOLSTENCROFT,${ }^{*}$ W. A. FRANKS,${ }^{* *}$ A. H. CHIGNELL ${ }^{* *}$, D. C. DUMONDE ${ }^{*}$ \\ London
}

\begin{abstract}
Summary
This study determined the presence of interleukin 1 (IL-1), interleukin 6 (IL-6), tumour necrosis factor $\alpha$ (TNF $\alpha)$, tumour necrosis factor $\beta$ (TNF $\beta)$, interferon $\gamma$ (IFN $\gamma$ ), transforming growth factor $\beta 2$ (TGF $\beta 2$ ) and fibroblast proliferation activity (FPA) in vitreous aspirates from eyes undergoing vitrectomy for the treatment of retinal detachment complicated by proliferative vitreoretinopathy (PVR) or uncomplicated retinal detachment (RD). Cadaveric vitreous from normal subjects were used as controls. The results showed that IL-1 and IL-6 predominated in vitreous from eyes with PVR or RD, and that concentrations of IL-6 $>20 \mathrm{pg} / \mathrm{ml}$ were more frequently found in PVR than in RD $(p=0.031)$ or control specimens $(p=0.006)$. Low levels of TNF $\alpha$ were observed in $4 / 18$ eyes with $P V R, 1 / 15$ eyes with $R D$ and $1 / 15$ control vitreous, and small concentrations of TNF $\alpha$ were seen in $3 / 18$ eyes with $P V R$, $1 / 15$ eyes with $R D$ and $2 / 15$ control vitreous. IFN $\gamma$ was detected in 12/18 eyes with PVR, but only in $5 / 15$ eyes with $R D(p=0.048)$ and $6 / 15$ control specimens. TGF $\beta 2$ was present in all vitreous samples at concentrations ranging from 100 to $4,500 \mathrm{pg} / \mathrm{ml}$ with no significant differences among the three groups. Control vitreous possessed the greatest FPA when compared with vitreous from eyes with PVR $(p=0.031)$ or RD $(p=0.048)$. These observations provide further evidence that cytokinemediated pathways of inflammation are involved in the pathogenesis of PVR and point to the possible involvement of IL-1, IL-6 and IFN $\gamma$ in cellular interactions leading to chronicity.
\end{abstract}

Proliferative vitreoretinopathy (PVR) is a well recognised complication of retinal detachment (RD). It is thought to be initiated as an inflammatory reaction ${ }^{1}$ which later results in the formation of contractile epiretinal membranes. ${ }^{2}$ These are composed of fibroblasts, macrophages, glial cells and retinal pigment epithelial cells, all bound into a framework of extracellular matrix proteins including fibronectin and collagen. Formation of epiretinal membranes involves cellular mechanisms of proliferation, migration and differentiation ${ }^{2}$ and cytokines, as inflammatory protein products of cell activation, are known to mediate these general cellular functions. ${ }^{3}$ On this basis, it is likely that cytokines may induce cell migration into epiretinal membranes, as well as contribute to cell growth and differentiation towards the contractile state responsible for the pathology of PVR.

In this study we have investigated vitreous aspirates for the presence of the cytokines interleukin 1 (IL-1), interleukin 6 (IL-6),

From: *Department of Immunology and ${ }^{* *}$ Eye Department, St Thomas' Hospital, UMDS, London and $\dagger$ National Institute for Biological Standards and Control, South Mimms, Herts.

Correspondence to: Dr. G. A. Limb, Immunology Research Unit, The Rayne Insitute, St Thomas' Hospital, Lambeth Palace Road, London SE1 7EH, UK. 
tumour necrosis factor $\alpha(\mathrm{TNF} \alpha)$, tumour necrosis factor $\beta$ (TNF $\beta)$, interferon $\gamma$ (IFN $\gamma$ ), transforming growth factor $\beta 2$ (TGF $\beta 2$ ) and fibroblast proliferation activity (FPA) in eyes undergoing vitrectomy for PVR or uncomplicated RD. Cadaveric vitreous from subjects with no known eye disease were used as controls.

\section{Materials and Methods}

\section{Vitreous specimens}

Vitreous samples were obtained from eyes undergoing vitrectomy for the treatment of RD complicated by proliferative vitreoretinopathy (PVR) (44 specimens) or from eyes with uncomplicated retinal detachment (RD) (24 specimens). Control (cadaveric) vitreous specimens were obtained from 20 subjects with no known eye disease within 24 hours post mortem. An inferotemporal sclerotomy was made $4 \mathrm{~mm}$ from the limbus in phakic eyes and $3.5 \mathrm{~mm}$ in aphakic or pseudophakic eyes. A $4 \mathrm{~mm}$ infusion cannula was inserted and its position in the vitreous cavity checked by direct vision. A superotemporal sclerotomy was made at the same distance from the limbus and an unprimed ocutome was passed into the centre of the vitreous cavity. Gel was cut and aspirated using a cutting speed of approximately $300 \mathrm{~Hz} /$ minute. Intraocular pressure was maintained by indentation. When an adequate sample was obtained the outcome was withdrawn and the infusion commenced to restore ocular volume. The vitreous specimen (approximately $0.75 \mathrm{ml}$ ) was aspirated from the ocutome tubing into a $5 \mathrm{ml}$ syringe, transferred to $1.8 \mathrm{ml}$ polypropylene tubes (Nunc, England) and stored at -20 degrees $\mathrm{C}$ until use. The severity of PVR was graded according to the 1983 criteria of the Retina Society Terminology Committee. ${ }^{4}$

\section{Investigation for the presence of cytokines in vitreous humour}

a) Interleukin 1 (IL-1)

This assay was based on a coculture system utilising EL-4 and CTLL cells. ${ }^{5}$ Both cell lines were cultured in RPMI 1640 medium supplemented with $10 \%$ fetal calf serum (FCS), $100 \mathrm{U} / \mathrm{ml}$ penicillin, $40 \mu \mathrm{g} / \mathrm{ml}$ gentamicin and $5 \times 10^{-5} \mathrm{M}$ 2-mercaptoethanol (2-ME). Before the assay, the cells were centrifuged at
$400 \mathrm{~g}$ for five minutes, washed twice with RPMI and adjusted to a concentration of $2 \times 10^{4}$ CTLL cells $/ \mathrm{ml}$ and $5 \times 10^{5}$ EL4 cells $/ \mathrm{ml}$. One hundred $\mu \mathrm{l}$ of these suspensions were added to $100 \mu \mathrm{l}$ of serial vitreous dilutions (in quadruplicate) in flat-bottomed 96well microtitre plates (Costar, England), and the mixture incubated for 24 hours at 37 degrees $\mathrm{C}$ in a humidified $5 \% \mathrm{CO}_{2}$ air atmosphere. Fifty $\mu \mathrm{l}$ of medium containing 0.25 $\mu \mathrm{Ci}$ of tritiated thymidine (TRA 120 , Amersham, England) were then added to each well and the incubation continued for a further 24 hours. Cells were harvested onto glass fibre filter discs (Whatman, England) and cellassociated radioactivity was measured in an LKB beta counter, model 1216. Levels of IL-1 were interpolated from specific calibration curves using a human IL1 $\beta$ standard preparation (gift of Dr. N. Smithers, Glaxo Groúp Research Ltd, Greenford). This technique has a detection limit of approximately $0.1 \mathrm{pg} / \mathrm{ml}$.

\section{b) Interleukin $6(I L-6)$}

Levels of IL- 6 were determined by proliferation of the IL- 6 dependent hybridoma cell line 7 TD $1^{6}$ (a gift of Dr. J. van Snick, Ludwig Institute for Cancer Research, Brussels). Hybridoma cells were cultured in RPMI 1640 medium supplemented with $5 \times 10^{-5} \mathrm{M} 2-\mathrm{ME}$, $10 \% \mathrm{FCS}, 200 \mathrm{U} / \mathrm{ml}$ penicillin, $40 \mu \mathrm{g} / \mathrm{ml}$ gentamicin and $200 \mathrm{U} / \mathrm{ml}$ murine recombinant IL-6. Prior to the assay the cells were washed twice with culture medium without IL-6 and resuspended at a concentration of $2 \times 10^{4} / \mathrm{ml}$ in the same medium. Equal volumes $(100 \mu \mathrm{l})$ of this cell suspension and serial 10 -fold dilutions of the vitreous specimens were admixed (in quadruplicate) in 96-well flat-bottomed microtitre plates (Costar, England) and cultured for four days at 37 degrees $C$ in a humidified $5 \% \quad \mathrm{CO}_{2}$-air atmosphere. Cell density was evaluated by colorimetric determination of hexosaminidase levels by incubating the cell pellets for four hours at 37 degrees $C$ with $60 \mu \mathrm{l}$ of hexosaminidase substrate (1 vol $7.5 \mathrm{mM}$ p-nitrophenyl-N-acetyl-b-D-glucosaminide in $0.1 \mathrm{M}$ sodium citrate $\mathrm{pH} 5.0+1 \mathrm{vol}$ $0.5 \%$ Triton $\mathrm{X}-100)$, followed by addition of $90 \mu \mathrm{l}$ of $0.1 \mathrm{M}$ glycine- $\mathrm{NaOH}$ buffer $\mathrm{pH} 10.4$. $^{7}$ Absorbance was read at $405 \mathrm{~nm}$ in a Titertek 
Multiscan and levels of IL-6 were interpolated from specific calibration curves using a human IL-6. standard preparation (a gift of Dr. W. Sebald, Institute of Physiology, Wurzburg, Germany). This technique had a detection limit of approximately $2 \mathrm{pg} / \mathrm{ml}$.

c) Tumour necrosis factor $\alpha(T N F \alpha)$, tumour necrosis factor $\beta$ (TNF $\beta)$ and Interferon $\gamma(I F N \gamma)$

Concentrations of TNF $\alpha$, TNF $\beta$ and IFN $\gamma$ in the vitreous specimens were determined by enzyme-linked immunosorbent assays (ELISA) ${ }^{8,9}$ Polyvinylchloride U-bottomed microtitre plates were coated with $50 \mu \mathrm{l}$ of purified rabbit polyclonal antibodies to TNF $\alpha$, TNF $\beta$ or IFN $\gamma$ for $2 h$ at 37 degrees C. Uncoated sites in the wells were blocked by overnight incubation of the plates at 4 degrees with $2 \%$ bovine serum albumin in phosphatebuffered saline (PBS) $(150 \mu \mathrm{l} /$ well $)$. After the incubation, excess antibodies and blocking buffer were removed and the wells washed four times with $0.05 \%$ Tween 20-PBS. Samples and serial dilutions of cytokine standards $(50 \mu \mathrm{l} /$ well $)$ were added to the wells and incubated for one hour at 37 degrees $C$ (all standards were prepared at the National Institute for Biological Standards and Control (NIBSC) Cat. Nos. 87/650 for TNF $\alpha, 87 / 640$ for TNF $\beta$ and $82 / 587$ for IFN $\gamma$ ). The cells were washed again four times with $0.05 \%$ Tween 20-PBS followed by five sequential procedures:

(i) addition of $50 \mu \mathrm{l} /$ well of optimal dilutions of either monoclonal antibody (MoAb) 3-101-23 detecting TNF $\alpha$, MoAb L81-11 detecting TNF $\beta$ and MoAb 4S.B3 detecting IFN $\gamma$ (all antibodies prepared at NIBSC);

(ii) incubation for one hour at 37 degrees C;

(iii) washing with $0.05 \%$ Tween 20 -PBS, addition of $50 \mu \mathrm{l} /$ well of biotinylated sheep anti-mouse immunoglobulin (Amersham, England) and incubation for one hour at 37 degrees $C$;

(iv) washing with $0.05 \%$ Tween $20-\mathrm{PBS}$, addition of $50 \mu \mathrm{l} /$ well of streptavidinbiotinylated horseradish peroxidase complex (Amersham, England) and incubation for $30 \mathrm{~min}$ at 37 degrees $\mathrm{C}$;

(v) washing the wells three times with
Tween 20-PBS and twice with $0.1 \mathrm{M}$ citrate/phosphate buffer, $\mathrm{pH}$ 5.0, and developing colour in the dark with addition of the substrate 0 -phenylenediamine $(1 \mathrm{mg} / \mathrm{ml}$ in $0.1 \mathrm{M}$ citrate/phosphate buffer containing $0.006 \% \mathrm{H}_{2} \mathrm{O}_{2}$ ). The colour reaction was stopped after $30 \mathrm{~min}$ by addition of $50 \mu \mathrm{l}$ $1 \mathrm{M} \mathrm{H}_{2} \mathrm{SO}_{4}$ to each well and the optical density read at $492 \mathrm{~nm}$ in a Titertek Multiscan. Levels of cytokine present in the culture supernatants were interpolated from specific calibration curves. The technique had a detection limit of approximately $2 \mathrm{U} / \mathrm{ml}$ for $\mathrm{TNF} \alpha, 3 \mathrm{U} / \mathrm{ml}$ for TNF $\beta$ and $0.5 \mathrm{U} / \mathrm{ml}$ for IFN $\gamma .{ }^{8,9}$ All three ELISA tests were highly specific for their respective cytokines and no cross-reactivity was observed.

\section{d) Transforming growth factor $\beta 2$ (TGF $\beta 2$ )} Vitreous concentrations of TGF $\beta 2$ were determined by an enzyme-linked immunosorbent assay (ELISA) using the monoclonal antibodies 3C7.14 and 1D11.16 against TGF $\beta 2$ (a gift from Dr. Y. Ogawa, Celltrix Laboratories, Palo Alto, CA). Wells of microtitre ELISA plates were coated with the 3C7.14 monoclonal antibody diluted to 5 $\mu \mathrm{g} / \mathrm{ml}$ in sodium bicarbonate buffer, $\mathrm{pH} 9.6$ ( $50 \mu \mathrm{l}$ per well) for two hours at 38 degrees $C_{\text {, }}$ and then blocked with a $1 \%$ human serum albumin (HSA) in the same buffer $(150 \mu \mathrm{l}$ per well) overnight at 4 degrees $C$. Monoclonal antibody and HSA buffer were removed and wells washed three times with $200 \mu \mathrm{l} 0.05 \%$ Tween 20-PBS (TW20-PBS). Following the last wash, serial dilutions of the TGF $\beta_{2}$ stan dard (NIBSC Cat. No. 89/518) or vitreous samples were placed into wells $(50 \mu \mathrm{l}$ per well) and incubated for one hour at 37 degrees $C_{\text {it }}$ Wells were re-washed with TW20-PBS and then a 1:100 dilution of biotinylated 1D11.16 monoclonal antibody was added to all wells $(50 \mu \mathrm{l} /$ well $)$ and incubation continued for one hour at 37 degrees C. (Biotinylation of 1D11.16 was carried out using reagents supplied in kit form by Amersham [England].) Following a further washing stage, streptavi. din biotinylated horseradish peroxidase com plex (Amersham, England), diluted 1:500 in $1 \%$ HSA-PBS, was added to all wells and 


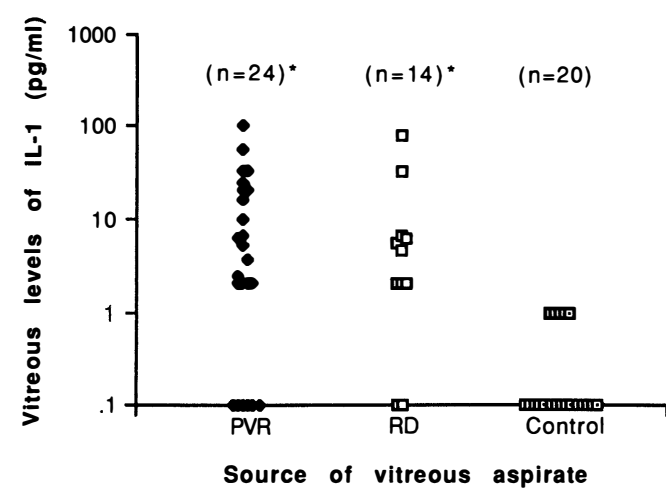

Fig. 1. Levels of interleukin 1 (IL-1) in vitreous aspirates from eyes with complicated. (PVR) or uncomplicated retinal detachment $(R D)$ and cadaveric eyes (control). $n=$ number of samples; ${ }^{*} p=0.0001(v$. control).

incubation continued for 30 minutes at 37 degrees C. Following extensive washing, substrate, orthophenylene-diamine $(1 \mathrm{mg} / \mathrm{ml})$ in $0.1 \mathrm{M}$ citrate/phosphate buffer, $\mathrm{pH} 5.0$, containing $0.006 \% \mathrm{H}_{2} \mathrm{O}_{2}$ was added and colour developed in the dark for 10-20 minutes. The reaction was terminated by the addition of $1 \mathrm{M}$ $\mathrm{H}_{2} \mathrm{SO}_{4}(50 \mu \mathrm{l} /$ well $)$ and optical densities were read at $492 \mathrm{~mm}$ in a Titertek Multiscan. The technique had a detection limit of $100 \mathrm{pg} / \mathrm{ml}$ and a linear calibration curve over the range $0.25-40 \mathrm{ng} / \mathrm{ml}$.

\section{e) Fibroblast proliferation activity (FPA)}

This assay was based on the proliferation of VERO cells (a monkey fibroblast cell line). ${ }^{10}$ VERO cells were grown as monolayers in $75 \mathrm{~cm}^{2}$ tissue culture flasks (Costar, England) using RPMI 1640 medium supplemented with $5 \%$ FCS, $200 \mathrm{U} / \mathrm{ml}$ penicillin and $40 \mu \mathrm{g} / \mathrm{ml}$ gentamicin. To obtain a single cell suspension, the monolayers were incubated for five min at 37 degrees C with $4 \mathrm{ml}$ of Hanks' balanced salt solution (HBSS) containing 0.5 $\mathrm{g} / \mathrm{l}$ trypsin and $0.2 \mathrm{~g} / \mathrm{l} \mathrm{Na}$ EDTA (Sigma, USA). The cells were then washed once with culture medium containing 5\% FCS and resuspended at a concentration of $1 \times 10^{5} \mathrm{ml}$ in HBSS containing $1 \%$ FCS. One hundred $\mu \mathrm{l}$ volumes of the cell suspension were placed in 96-well flat-bottomed microtitre plates (Costar, England) and incubated overnight at 37 degrees $\mathrm{C}$ in a $5 \% \mathrm{CO}_{2}$-air atmosphere. Equal volumes of control medium or serial 10 -fold dilutions of the test vitreous specimens were then added (in quadruplicate) to the cells and the incubation continued for a further 48 hours. The cells were then pulsed with 0.1 $\mu \mathrm{Ci} /$ well of $3 \mathrm{H}$ thymidine (TRA 120 , Amersham, England) for 16 hours at 37 degrees $C$ and the medium aspirated and replaced with $100 \mu \mathrm{l}$ of trypsin-EDTA solution (Sigma, USA), followed by incubation for $15 \mathrm{~min}$ at 37 degrees C. Cells were harvested onto glass fibre filter discs (Whatman, England) and cell-associated radioactivity was measured in an LKB Beta counter, model 1216. Human interleukin $1 \beta$ was used as a positive control for fibroblast proliferation activity (FPA). The results were expressed as an 'FPA index' calculated by the following formula:

$$
\frac{\mathrm{cpm} \text { test }-\mathrm{cpm} \text { control }}{\mathrm{cpm} \text { control }} \times 100
$$

\section{Statistical methods}

The significance of differences between corresponding groups of observations was evaluated by chi-squared analysis using Fisher's exact test after constructing $2 \times 2$ contingency tables. Acceptable significance was recorded when p-values were $<0.05$.

\section{Results}

\section{Levels of IL-1 in vitreous aspirates}

Vitreous from eyes with both complicated (PVR) and uncomplicated RD contained higher concentrations of IL-1 ( $>1 \mathrm{pg} / \mathrm{ml})$ than the control group $(\mathrm{p}<0.0001)$ (Fig. 1). Levels

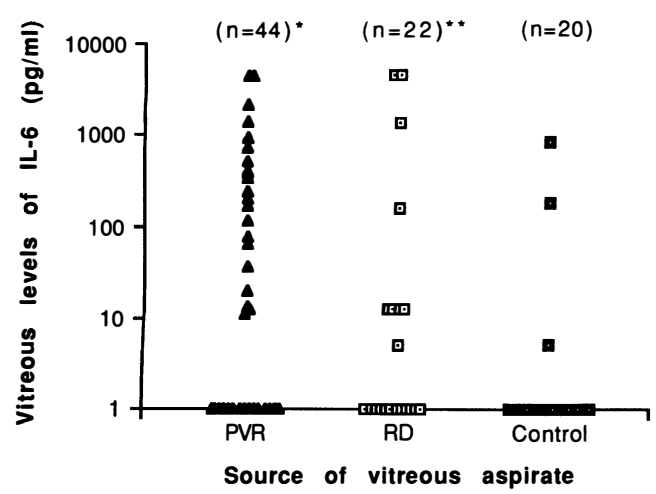

Fig. 2. Levels of interleukin 6 (IL-6) in vitreous aspirates from eyes with complicated (PVR) or uncomplicated retinal detachment $(R D)$ and cadaveric eyes (control). $n=$ number of samples; ${ }^{*} p=0.0007(v$. control); ${ }^{* *} p=0.014$ (v. control). 
Table I Levels of tumour necrosis factors $\alpha$ and $\beta$ (TNF $\alpha$ and TNF $\beta$ ), and interferon $\gamma$ (IFN $\gamma)$ in vitreous aspirates*.

\begin{tabular}{|c|c|c|c|c|c|}
\hline $\begin{array}{l}\text { Source of } \\
\text { vitreous aspirates }\end{array}$ & $\begin{array}{c}\text { Severity (grade) + } \\
\text { of PVR }\end{array}$ & Patient No & $\begin{array}{l}T N F \alpha \\
(U / m l)\end{array}$ & $\begin{array}{l}T N F \beta \\
(U / m l)\end{array}$ & $\begin{array}{l}I F N \gamma \\
(U / m l)\end{array}$ \\
\hline $\begin{array}{l}\text { Retinal detachment } \\
\text { complicated by PVR }\end{array}$ & $\begin{array}{l}\text { D2 } \\
\text { C1 } \\
\text { D2 } \\
\text { C1 } \\
\text { D2 } \\
\text { B } \\
\text { D1 } \\
\text { B } \\
\text { B } \\
\text { C1 } \\
\text { C1 } \\
\text { D2 } \\
\text { B } \\
\text { B } \\
\text { C1 } \\
\text { C2 } \\
\text { C2 } \\
\text { C3 }\end{array}$ & $\begin{array}{l}11 \\
20 \\
30 \\
31 \\
33 \\
52 \\
56 \\
63 \\
66 \\
74 \\
75 \\
79 \\
80 \\
81 \\
50 \\
59 \\
65 \\
54\end{array}$ & $\begin{array}{l}<2 \\
<2 \\
<2 \\
<2 \\
<2 \\
12 \\
<2 \\
<2 \\
2 \\
<2 \\
2.5 \\
2.5 \\
2 . \\
<2 \\
<2 \\
<2 \\
<2 \\
<2 \\
<2\end{array}$ & $\begin{array}{r}<3 \\
<3 \\
<3 \\
<3 \\
32 \\
<3 \\
<3 \\
<3 \\
5 \\
<3 \\
<3 \\
<3 \\
<3 \\
<3 \\
<3 \\
6 \\
<3 \\
<3 \\
<3 \\
<3\end{array}$ & $\begin{array}{c}1 \\
3 \\
8 \\
<0.5 \\
2 \\
1 \\
0.8 \\
0.9 \\
0.8 \\
0.5 \\
1.1 \\
0.9 \\
<0.5 \\
<0.5 \\
1.3 \\
<0.5 \\
<0.5 \\
<0.5\end{array}$ \\
\hline $\begin{array}{l}\text { Retinal detachment not } \\
\text { complicated by PVR }\end{array}$ & $\begin{array}{l} \pm \\
= \\
= \\
= \\
= \\
= \\
= \\
= \\
=\end{array}$ & $\begin{array}{l}32 \\
34 \\
35 \\
36 \\
49 \\
53 \\
55 \\
57 \\
58 \\
60 \\
71 \\
72 \\
76 \\
83 \\
84\end{array}$ & $\begin{array}{l}<2 \\
<2 \\
<2 \\
<2 \\
<2 \\
<2 \\
<2 \\
<2 \\
<2 \\
<2 \\
<2 \\
<2 \\
2 \\
<2 \\
<2 \\
<2\end{array}$ & $\begin{array}{r}<3 \\
<3 \\
<3 \\
<3 \\
<3 \\
<3 \\
<3 \\
5 \\
<3 \\
<3 \\
<3 \\
<3 \\
<3 \\
<3 \\
<3 \\
<3 \\
<3\end{array}$ & $\begin{array}{r}<0.5 \\
<0.5 \\
<0.5 \\
2 \\
2 \\
<0.5 \\
<0.5 \\
0.5 \\
<0.5 \\
<0.5 \\
<0.5 \\
0.9 \\
<0.5 \\
0.9 \\
<0.5\end{array}$ \\
\hline Controls (cadaveric eyes) & $\begin{array}{l}= \\
= \\
= \\
= \\
= \\
= \\
= \\
= \\
=\end{array}$ & $\begin{array}{l}17 \\
19 \\
21 \\
23 \\
26 \\
27 \\
41 \\
44 \\
45 \\
46 \\
67 \\
68 \\
77 \\
78 \\
82\end{array}$ & $\begin{array}{l}<2 \\
<2 \\
<2 \\
<2 \\
<2 \\
<2 \\
<2 \\
<2 \\
<2 \\
8 \\
82 \\
<2 \\
<2 \\
<2 \\
<2 \\
\quad 2\end{array}$ & $\begin{array}{r}8 \\
<3 \\
<3 \\
<3 \\
<3 \\
<3 \\
<3 \\
<3 \\
<3 \\
<3 \\
<3 \\
60 \\
<3 \\
<3 \\
<3 \\
<3 \\
<3\end{array}$ & $\begin{array}{c}<0.5 \\
1 \\
2 \\
2.5 \\
<0.5 \\
<0.5 \\
<0.5 \\
2 \\
1 \\
2 \\
<0.5 \\
<0.5 \\
<0.5 \\
<0.5 \\
<0.5\end{array}$ \\
\hline
\end{tabular}

${ }^{*}<=$ Indicates the limits of detectability

$+=$ Severity of PVR graded by established criteria (ref 4$)$

of IL-1 $>1 \mathrm{pg} / \mathrm{ml}$ were observed in 18 of 24 vitreous from eyes with PVR and nine of 14 vit- reous from eyes with uncomplicated $\mathrm{RD}$. All control specimens contained $\leqslant 1 \mathrm{pg} / \mathrm{ml}$ of this 


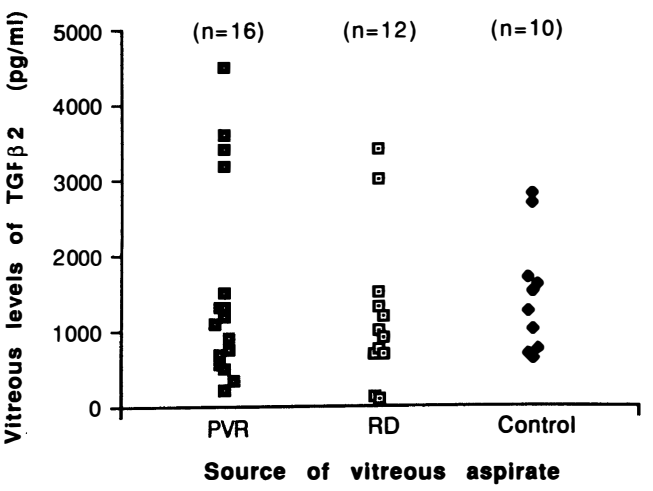

Fig. 3. Levels of transforming growth factor $\beta 2$ (TGFB2) in vitreous aspirates from eyes with complicated (PVR) or uncomplicated retinal detachment (RD) and cadaveric eyes (control). $n=$ number of samples.

cytokine. There was no relationship between the levels of IL-1 in the vitreous specimens and the severity of PVR.

\section{Levels of IL-6 in vitreous aspirates}

IL-6 was present in 22 of 44 vitreous from eyes with PVR ( $p=0.0007)$, nine of 22 vitreous from eyes with $\mathrm{RD}(\mathrm{p}=0.014)$ compared with two of 20 control specimens (Fig. 2). Levels $>20 \mathrm{pg} / \mathrm{ml}$ of this cytokine were present in 19 of the 44 specimens from eyes with PVR in contrast to four of 22 specimens from eyes with uncomplicated RD $(\mathrm{p}=0.031)$ and two of 20 control samples $(p=0.006)$. There was no significant difference between vitreous from eyes wtih uncomplicated RD and vitreous from control eyes in their range of IL-6 concentrations. Moreover, there was no relationship between the levels of IL- 6 in the vitreous samples and the severity of PVR.

\section{Levels of $T N F \alpha, T N F \beta$ and IFN $\gamma$ in vitreous aspirates}

Table I shows the concentrations of TNF $\alpha$, TNF $\beta$ and IFN $\gamma$ in vitreous samples from all three groups. TNF $\alpha$ was observed at low levels in four of 18 specimens from eyes with PVR, in one of 15 specimens from eyes with uncomplicated RD, and in one of 15 control vitreous. TNF $\beta$ was detected in three of 18 vitreous from eyes with PVR, one of 15 samples from eyes with uncomplicated $\mathrm{RD}$, and two of 15 control vitreous. There were no significant differences among the three groups of vit- reous samples with respect to levels of TNF $\alpha$ or TNF $\beta$. IFN $\gamma$ was detected in 12 of 18 vitreous from eyes with PVR, but only in five of 15 vitreous from eyes with uncomplicated $R D$ $(\mathrm{p}=0.048)$ and six of 15 control specimens. In vitreous samples where IFN $\gamma$ was detected, there were no significant differences in the range of IFN $\gamma$ concentrations among samples from eyes with PVR, uncomplicated RD or the control group.

\section{Levels of TGF 2 in vitreous aspirates}

Figure 3 shows that all vitreous analysed contained TGF $\beta 2$ at levels ranging from 100 to $4,500 \mathrm{pg} / \mathrm{ml}$. There were no significant differences in the concentrations of this cytokine among the three groups of vitreous studied.

\section{Presence of FPA in vitreous aspirates}

Figure 4 shows that an FPA index $\geqslant 20 \%$ was observed in one of 16 specimens from eyes with PVR, one of 14 specimens from eyes with uncomplicated RD and 10 of 19 control vitreous. Statistical analysis of the results showed that vitreous from control eyes possessed the greatest FPA when compared with vitreous obtained from eyes with PVR $(\mathrm{p}=0.031)$ or uncomplicated RD $(\mathrm{p}=0.048)$.

\section{Discussion}

This study shows that IL- 1 and IL- 6 are the predominant cytokines found in vitreous aspirates from patients with proliferative vitreoretinopathy (PVR) or uncomplicated retinal

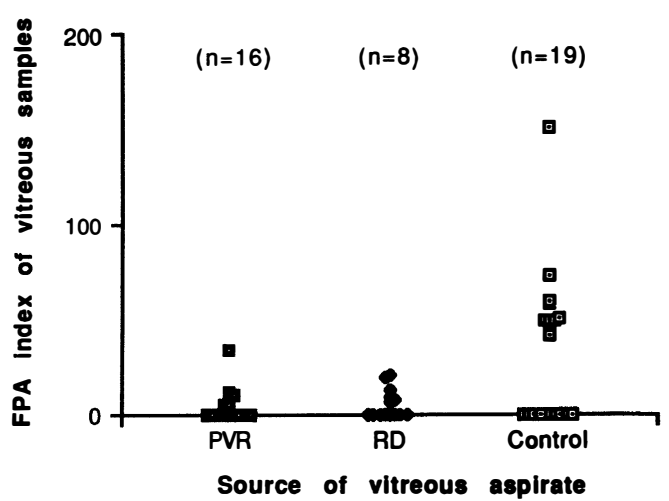

Fig. 4. Levels of fibroblast proliferation activity (FPA index) in vitreous aspirates from eyes with complicated $(P V R)$ or uncomplicated retinal detachment $(R D)$ and cadaveric eyes (control). $n=$ number of samples. 
detachment (RD), but that high concentrations of IL-6 $(>20 \mathrm{pg} / \mathrm{ml})$ were more frequent in PVR than in uncomplicated RD.

Several cell types may contribute to the presence of cytokines in vitreous humour. These may include resident cells involved in epiretinal membrane formation such as local macrophages, fibroblasts and glial cells ${ }^{11}$, or they may enter from the blood due to breakdown of the blood retinal barrier. The presence of IL-1 in vitreous from eyes with retinal detachment has been previously reported ${ }^{12}$ but the presence of IL-6 in eyes with PVR or uncomplicated RD has not hitherto been documented. Both IL-1 and IL-6 mediate inflammatory cell functions, such as cell growth, migration and differentiation; ${ }^{13,14}$ they overlap in their functions and IL-1 is a potent inducer of IL- 6 expression in many cell types. ${ }^{15}$ On this basis the high concentration of IL- 6 in vitreous from eyes with PVR indicates that this cytokine may well play a significant role in progression of the disease.

That the cytokine IFN $\gamma$ was more often detected in vitreous from eyes with PVR than in uncomplicated RD or cadaveric eyes suggests that blood-borne lymphoid cells and monocytes may interact with resident cells during the development of PVR resulting in local release of this cytokine. Interferon $\gamma$ is known to upregulate MHC Class II molecule expression on retinal pigment epithelial cells ${ }^{16}$ in a similar fashion to its action on mononuclear phagocytes $;{ }^{17}$ and there is enhancement of the capacity of mononuclear cells to present foreign antigens to recirculatory $T$ lymphocytes. ${ }^{17}$ Experimental studies show that epiretinal membrane formation can be accompanied by infiltration of blood-borne lymphocytes and monocytes, which persist until the late stages of experimental PVR. ${ }^{18.19}$ A requirement for chronic inflammation to be dependent upon cytokine-mediated recruitment of blood mononuclear leucocytes and their interaction with resident cells has been postulated in other sites, such as the skin. ${ }^{20}$

A report that TGF $\beta 2$ levels are higher in vitreous from eyes with PVR than in uncomplicated $\mathrm{RD}^{21}$ was not confirmed in this study. This may be due to differences in methodology: for in the previous report a biological assay was used which requires in vitro acti- vation of TGF $\beta 2$, and only measures biologically active molecules. In this study we assayed TGF $\beta 2$ immunochemically, and thus measured all immunoreactive TGF $\beta 2$ available. On this basis our finding of high levels of bioactive FAF in cadaveric vitreous suggests that this cytokine may simply be a product of tissue degeneration.

The present study supports growing evidence that cytokine-mediated pathways of chronic inflammation are involved in the pathogenesis of PVR, and draws attention to the possibility that interaction between bloodderived inflammatory leucocytes and resident cells of the retina may underlie the development and chronicity of this condition. Retinal pigment epithelial cells are known to produce chemotactic and mitogenic factors, active upon glial cells, monocytes and fibroblasts, ${ }^{22}$ and whose secretion may well be enhanced by cytokines such as IL-1, IL-6 and IFN $\gamma$. Activated macrophages and fibroblasts, migrating in response to pigment epithelial cell factors, may then secrete excessive amounts of matrix proteins such as collagen and fibronectin ${ }^{1,23}$ leading to gel contraction and epiretinal membrane formation. The presence of extracellular matrix proteins, in addition to these cytokines and oth $\in \mathrm{r}$ inflammatory mediators, may then generate a local microenvironment which favours the development of epiretinal membranes. We suggest that the pathogenesis of PVR involves a switch in mechanisms that normally regulate cytokine production by blood-borne inflammatory cells that infiltrate the retinal microenvironment following surgical intervention. Identification of the particular cytokines involved could be of therapeutic as well as pathogenetic importance.

We thank the Trustees of the Gift of Thomas Pocklington for the award of a Pocklington Trust Research Fellowship (to GAL), the Research (Endowments) Committee of St Thomas' Hospital for research support, and Mrs. Dora Paterson for typing the manuscript.

\section{References}

${ }^{1}$ Gilbert C, Hiscott P, Unger W, Grierson I, McLeod $\mathrm{D}$ : Inflammation and the formation of epiretinal membranes. Eye 1988, 2: Suppl. S140-56.

${ }^{2}$ Wiedemann P and Weller M: The pathophysiology of proliferative, vitreoretinopathy. Acta Ophthalmologica 1988, 189: Suppl. 7-15. 
${ }^{3}$ Mantovani A and Dejana E: Cytokines as communication signals between leukocytes and endothelial cells. Immunology Today 1989, 10: 370-5.

${ }^{4}$ The Retina Society Terminology Committee. The classification of retinal detachment with proliferative vitreoretinopathy. Ophthalmology 1983, 90: $121-5$.

${ }^{5}$ Gearins AJH, Bird CR, Bristow A, Poole S, Thorpe $\mathrm{R}$ : A simple, sensitive bioassay for IL-1 which is unresponsive to $10^{3} \mathrm{U} / \mathrm{ml}$ of IL-2. J Immunol Meth 1987, 99: 7-11.

${ }^{6}$ Van Snick J, Cayphas S, Vink A, Vyttenhove C, Coulie P, Simpson R: Purification and NH2-terminal amino acid sequence of a new $\mathrm{T}$ cell-derived lymphokine with growth factor activity for B cell hybridomas. Proc Natl Acad Sci USA 1986, 83: 9679-83.

${ }^{7}$ Landegren U: Measurement of cell numbers by means of the endogenous enzyme hexosaminidase. Applications to detection of lymphokines and cell surface antigens. J Immunol Meth 1984, 67: $379-88$.

${ }^{8}$ Meager A, Parti S, Leung H, Peil E, Mahon B: Preparation and characterisation of monoclonal antibodies directed against antigenic determinants of recombinant human tumour necrosis factor (rTNF). Hybridoma 1987a, 6: 305-11.

${ }^{9}$ Meager A, Parti S, Leung H, Woolley J, Peil E, Sidu S, Roberts T: A two-site sandwich assay of human lymphotoxin with monoclonal antibodies and its applications. J Immunol Meth 1987b, 104: 31-41.

${ }^{10}$ Clemens MJ, Morris AG, Gearing AJH: In: Lymphokines and interferons: a practical approach. IRL Press (England) 1987, p 278.

${ }^{11}$ Yamashita H, Hori S, Masuda K: Population and proportion of component cells in preretinal membranes. Jpn J Ophthalmol 1986, 30: 269-81.

${ }^{12}$ Davis JL, Jalkh AE, Roberge F, Caspi R, Flynn HW Jr, Schepens CL, Nussenblatt RB: Subretinal fluid from human retinal detachment contains interleukin 1. Invest Ophthalmol Vis Sci 1988, 29: Suppl. 396.

${ }^{13}$ Mantovani A and Dejana E: Cytokines as communication signals between leucocytes and endothelial cells. Immunol Today 1989, 10: 370-5.
${ }^{14}$ Wong GG and Clark SC: Multiple actions of interleukin 6 within a cytokine network. Immunol Today 1989, 9: 137-9.

${ }^{15}$ Van Snick J: Interleukin-6. An Overview. Ann Rev Immunol 1990, 8: 253-78.

${ }^{16}$ Jerdan JA, Pepose JS, Michels RG, Hayashi H, Bustros SD, Sebag M, Glaser BH: Proliferative vitreoretinopathy membranes. An immunocytochemical study. Ophthalmol 1989, 96: 801-10.

${ }^{17}$ Winchester RJ and Kunkel HG: The human Ia system. Adv Immunol 1979, 28: 221-92.

${ }^{18}$ Algvere P, Wallow IH, Martini B: The development of vitreous membranes and retinal detachment induced by intravitreal carbon microparticles. Graefe's Arch Clin Exp Ophthalmol 1988, 226: 471-8.

$1^{9}$ Hitchins CA and Grierson I: Intravitreal injection of fibroblasts: the pathological effects on the ocular tissues of the rabbit following an intravitreal injection of autologous skin fibroblasts. $\mathrm{Br} \mathrm{J} O$ phthalmol 1988, 72: 498-510.

${ }^{20}$ Brown KA, Ellis BA, Dumonde DC: Cytokines in relation to inflammatory skin disease. In: Graves HW and Shuster S eds. Pharmacology of the Skin. Handbook of Experimental Pharmacology, Berlin. Springer-Verlag (1989): 271-286.

${ }^{21}$ Conner TB, Roberts AB, Sporn MB, Danielpour D, Dart LL, Michels RG, de Bustros S, Enger C, Kato H, Lansing M, Hayashi H, Glaser BM: Correlation of fibrosis and transforming growth factor- $\beta$ type 2 levels in the eye. J Clin Invest 1989, 83: $1661-6$.

${ }^{22}$ Burke JM and Foster SJ: Induction of DNA synthesis by co-culture of retinal glia, and pigment epithelium. Invest Ophthalmol Vis Sci 1985, 26: 636-42.

${ }^{23}$ Weller M, Heimann K, Wiedemann P: Demonstration of mononuclear phagocytes in a human epiretinal membrane using a monoclonal antihuman macrophage antibody. Graefe's Arch Clin Exp Ophthalmol 1988, 226: 252-4. 